\title{
Content analysis of research papers on flipped learning
}

\section{Análisis de contenido de trabajos de investigación sobre aprendizaje invertido}

\author{
Blerta Prevalla Etemi \\ AAB University. Prishtina, Republic of Kosova \\ blerta.prevalla@universitetiaab.com \\ Huseyin Uzunboylu \\ Member of Higher Education Planning, Supervision, Accreditation and Coordination Board. North Cyprus, Turkey. \\ huseyin.uzunboylu@neu.edu.tr \\ Mentor Hamiti \\ South East European University. Tetovo, Macedonia. \\ m.hamiti@seeu.edu.mk
}

\begin{abstract}
The purpose of this study is to describe the current state of research publication and trends in flipped learning, found on 'Web of Science' during the period 2014-2018. There are 262 papers investigated, published and indexed on 'Web of Science' with the keyword: "flipped learning" and "flipped classroom". The results of the study are analysed according to the journal of publication by these criteria: author, countries, funding agencies, document types, languages, organisation, publication years and source title. Flipped learning changes the traditional lecturing by flipping the classroom in the sense of listening to the video lectures at home and doing dynamic, group-based activities in the classroom. This engages the students in active learning, critical thinking, and meliorates interpersonal skills.It is recommended to authors to explore the possibility of utilising this method, experimenting and publish the findings which allows to create best practices and a unified framework for leading instructors who want to adopt this teaching methodology.
\end{abstract}

Keywords: Flipped learning, flipped classroom, content analysis,

\section{Resumen}

El propósito de este estudio es describir el estado actual de la publicación de investigaciones y las tendencias en el aprendizaje invertido, que se encuentran en "Web of Science" durante el período 2014-2018. Hay 262 artículos investigados, publicados e indexados en "Web of Science" con la palabra clave: "aprendizaje invertido" y "aula invertida". Los resultados del estudio se analizan según la revista de publicación según estos criterios: autor, países, agencias de financiación, tipos de documentos, idiomas, organización, años de publicación y título de la fuente. El aprendizaje invertido cambia la clase tradicional dando la vuelta al aula en el

RED. Revista de Educación a Distancia. Núm. 66, Vol. 21. Artíc. 8, 30-Abril-2021

DOI: http://dx.doi.org/10.6018/red.451551 
sentido de escuchar las videoconferencias en casa y realizar actividades dinámicas en grupo en el aula. Esto involucra a los estudiantes en el aprendizaje activo, el pensamiento crítico y mejora las habilidades interpersonales. Se recomienda a los autores explorar la posibilidad de utilizar este método, experimentar y publicar los hallazgos que permitan crear mejores prácticas y un marco unificado para instructores líderes que deseen adoptar esta metodología de enseñanza.

Palabras clave: aprendizaje invertido, aula invertida, análisis de contenido,

\section{Introduction}

With the expansion of web based learning and the improvement of instructive technologies, various universities and instructors are endeavouring to provide qualified teaching, including flipped learning by doing things in an opposite way: the teacher 'distributes' lectures before class in the form of pre-recorded videos, and during the class time engages on learning activities with students that include cooperation and interaction (Uzunboylu \& Kocakoyun, 2017). Implying that the flipped learning advocates' in-class interactive teamwork and learning and out-of-class guidance through video recordings or podcasts. Instinctively, this methodology moves classroom time away from insignificant spread of data and allows teachers to concentrate on solving student issues and empowering learning (Bagriyanik \& Karahoca, 2016; Gursakal \& Bozkurt, 2017). In the flipped classroom environment students participate in class exercises more actively rather than in the traditional classroom. (Uzunboylu \& Karagozlu, 2015).

Despite the fact that the concept of flipped classroom isn't new, there are few researches and publications during the last 5 years that support this study. Flipped learning has its origin back in the 2000s as an idea of schoolwork association related with the work of Wesley Baker exhibited in the 11th International Conference on College Teaching and Learning, Florida.

The concept of 'flipping the classroom' was initially presented utilizing learning management tools based on the web; and around the same time, Lage, Platt and Treglia (2000) featured the adverse effects of the apparent gap between current teaching and the learning style of the students. Flipped learning gains its ubiquity when Bergmann and Sams (2007), habitually cited as the pioneers of the application of the idea of flipped learning, began to apply this reversed classroom

Content analysis of research papers on flipped learning. Huseyin Uzunboylu, Blerta Prevalle Ethemi y Mentor Hamidi. 
by recording live classes, lectures, demonstrations and presentations with annotated slides, so the students would not miss any lecture and had their ultimate achievement.

Content analysis of papers published in academic journals has been conducted in numerous professional fields like: informatics, economics, engineering, chemistry, linguistics, nursing, psychology, nuclear medicine and etc (Cupal, 2016).

Because of sophisticated internet technology as well as contemporary digital techniques, developed countries such as the United States of America, Australia, China and Canada have introduced flipped learning strategy to reform their instructional system (Kissi, Nat, \& Idowu, 2017).

Even though traditional learning strategy is the most widely used teaching methodology in higher education, still, it can often position learners in an inactive role, which often involves students learn isolated facts that can be forgotten later, that is why flipped learning is a form of blended learning that has become a prominent instructional strategy and trend within the past 10 years (Ceker \& Ozdamli, 2016).

These past few decades, teachers have changed the traditional teaching methodology by extending the technology use as an approach to broaden and improve the understanding and knowledge of students'. One tactic lately embraced by a lot of stakeholders is the flipped learning methodology: students use internet to access lecture presentations and other educational tools outside the classroom, and spending the time in class for active learning through activities and practice exercises. (Bishop \& Verleger, 2013; Giannakos \& Chrisochoides, 2014; Kanbul \& Uzunboylu, 2017). Having watched the videos, they become ready to do some activities related to the videos. That is, the traditional "homework" becomes "school work" in a flipped learning environment. (Umutlu \& Akpinar, 2017).

The aim of this paper is to provide a review of recent research publications on the use of the flipped learning methodology in education based on the evolving video and teaching technology innovations. Firstly, it will be discussed about the authors and their contributions; then, the countries where flipped classroom researches are done mostly; next sections include discussions about document types, funding agencies, languages, research areas, organisations and what's most important, publications by years and how they evolve over the years. In conclusion,

Content analysis of research papers on flipped learning. Huseyin Uzunboylu, Blerta Prevalle Ethemi y Mentor Hamidi. 
this paper summarises the role of the flipped classroom in education and provides recommendations for the adaptation of the flipped classroom approach to teaching and learning activities according to the materials published on 'Web of Science'.

\section{Methodology}

In this study, its used quantitative analysis of the content conducted on the database of Web of Science, in order to release findings from articles published between 2014 and 2018 on the subject of the flipped classroom.

Web of science is a platform that gives access to the most credible materials, multidisciplinary researches linked through associated citation metrics from different sources. We can be guaranteed that just the most powerful, significant and reliable data are included because it holds to a strict assessment process, allowing us to reveal our next big idea quicker.

Web of Science being the most accurate, objective, and complete resource available has a multidisciplinary coverage of over 33,000 high impact journals, 180,000 proceedings from different conferences and more than 80000 books. ${ }^{1}$ The selection is based on impact assessments and includes journals with open-access that have spanned multiple academic disciplines over the past 100 years. The coverage of Web of Science Core Collections involves: social sciences, arts and humanities and goes across disciplines to allow you inspect the connections.

Furthermore, , the total file count of the Web of Science is over a billion of records, which includes over 11.4 billion cited references.

Using the keywords such as flipped learning, flipped classroom, content analysis are searched documents published and indexed during the period 2014-2018. There were found exactly 262 documents corresponding with the topics and are analysed in detail according to these criteria: author, countries funding agencies, document types, languages, organisation, publication years and source title. All keywords from each paper in the chosen database were categorized and collected from 2014 to 2018 . The data acquired from the literature review was analysed and divided into meaningful units and it was targeted to express each unit in terms of its conceptual meaning

\footnotetext{
${ }^{1}$ https://clarivate.com/products/web-of-science/databases/
}

Content analysis of research papers on flipped learning. Huseyin Uzunboylu, Blerta Prevalle Ethemi y Mentor Hamidi. 
(Uzunboylu and Cumhur, 2015). The results (data analysis) are sorted in an Excel file, statistically calculated and analysed which then produced the tables and chart as shown in the section above.

\section{Results}

\subsection{Data sorted by authors of 262 publications from 2014-2018}

On web of Science, there are 249 authors who have published papers related with flipped learning, moreover, 222 authors with single publication $(0.38 \%$ per author) 23 with two publications, $(0.76 \%$ per author) 3 authors with three publications (1.15\% per author), 1 with four publications (1.53\%) and Hwang GJ with 6 publications (2.29\%). Below, on Figure 1, we can see the chart with listed authors with more than one publication per author.

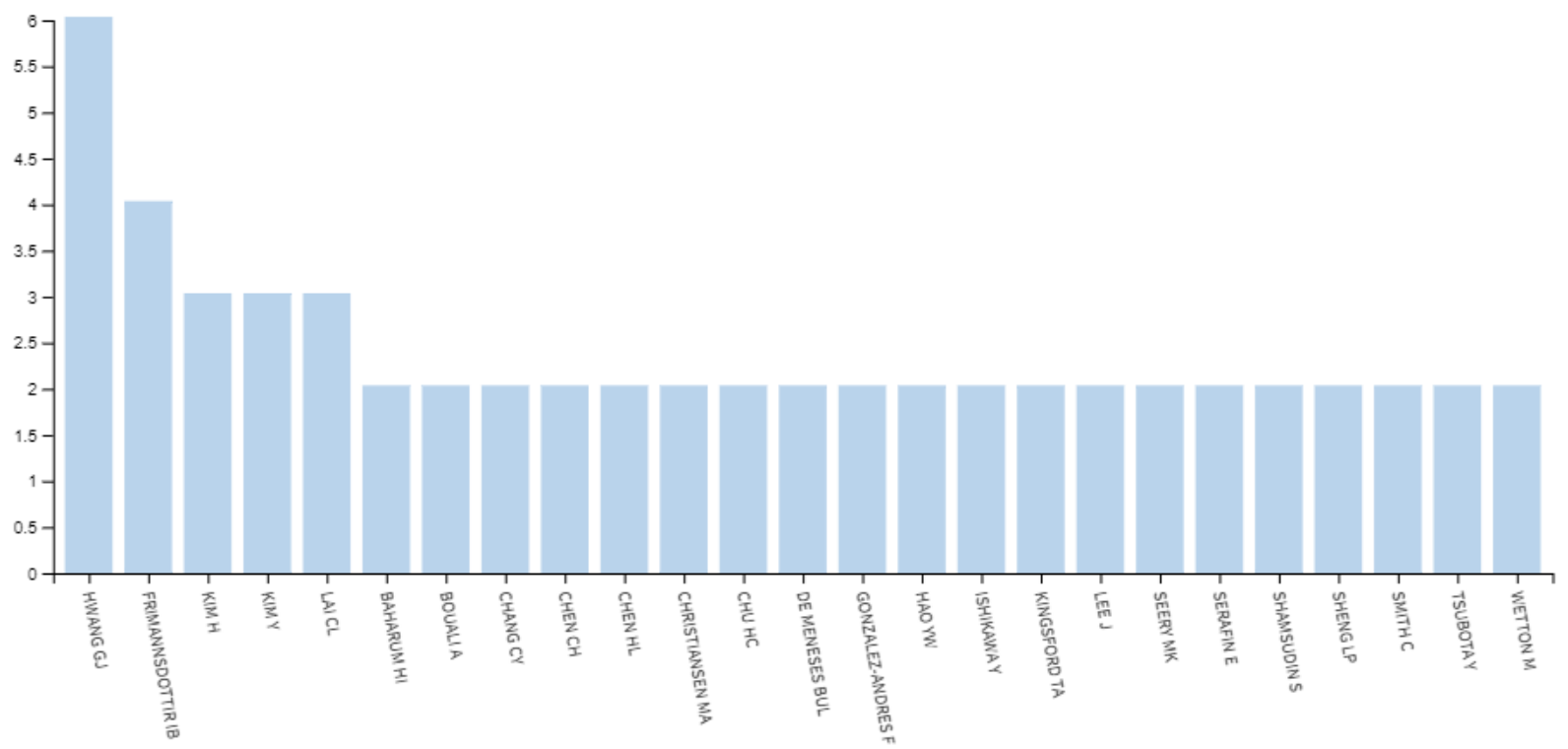

Figure 1. Number of publications per author, authors with more than one

According to the authors who have more articles published on this topic, for example, Hwang, reveals importance on three feasible headings for future investigations of this educational methodology like: longitudinal examinations, studying its impact on distinct teaching goals, and incorporation of gamification into flipped classroom. Then it is proposed a detailed structure for flipped classroom measures, consisting of four aspects: the history of the study, the layout of the course, course exercises, and intervention outcome (Hwang, 2018).

Content analysis of research papers on flipped learning. Huseyin Uzunboylu, Blerta Prevalle Ethemi y Mentor Hamidi. 
Hsieh, Huang and $\mathrm{Wu}(2017)$ analysed the technological acceptance of $\mathrm{LINE}^{2}$ in flipped classroom of English course, the oral preparation and have done a crucial examination of the elements integrated in English course for foreign learners' technological acceptance. The outcomes revealed beneficial impacts of the digital - based flipped instructions over the traditional approach with classical lectures, and show the function of the attitude towards the utilization of LINE in the subsequent behavioural objective of the learners to recognize the inclusion of such technology in language learning, albeit variations in the structure of the correlation between students of distinctive capability levels.

Wu, Hsieh and Yang (2017) research about improving learners of English as a foreign language oral capability by creating an online teaching environment in a flipped classroom continues to be inadequate and not enough. Accordingly, the current study analysed the effect of a study community connected online in a flipped classroom using mobile platforms, on the oral skill of learners' of English as foreign language and student recognitions. The outcomes from different sources showed that the learning community connected online not only encouraged successful cooperation, but also considerably enhanced oral skills of employees, contributing to more effective engagement in highly interactive learning activities such as narration, dialog cooperation, school debate and team presentations.Flipped learning has a lot of advantages like enhancing retention, makes learning easier, promotes regular study habits, improves comprehension skills and helps develop computer skills (Karadag \& Keskin, 2017).

Kim and Yung (2017) made a study intended to confirm the impacts of flipped classroom on the students' performance, collaborative abilities and levels of satisfaction of undergraduate nursing learners. As a result, the flipped classroom group received greater scores on academic performance, collaborative abilities and levels than the control group including material expertise and nursing practical ability.

Hao (2016) analyses the learning readiness for flipped classroom, and on his analyses, he found that approximately $60 \%$ liked the concept of flipped learning, but only $39 \%$ were positive about that the flipped classroom fulfilled their teaching and schooling requirements. The readiness rate of students for flipped learning was reasonably higher than the average rate, and males or

\footnotetext{
2 is an application that you can download for free to use it for immediate communications on electronic devices
}

Content analysis of research papers on flipped learning. Huseyin Uzunboylu, Blerta Prevalle Ethemi y Mentor Hamidi. 
youngsters felt more ready for flipped classroom. In general, course assessment, self-directed learning readiness and team work preference can anticipate the different readiness dimensions. In particular, the distinct aspects of readiness can be anticipated by subject assessment, self-directed teaching readiness and team work choice.

Uzunboylu, Hursen, Ozuturk and Demirok (2015) emphasised the benefit of mobile coordinated language teaching, and university students have favourable reactions to language learning utilizing mobile devices. Furthermore, it was likewise revealed that pre-service educators have favourable views on the use of technology in education (Birkollu, Yucesoy, Baglama \& Kanbul, 2017).

\subsection{Data analysis of publications by countries}

An interesting factor for analysing is also the countries that mostly contributed with publications in Web of Science about the flipped learning issues, and according to the analyses done, most published papers come from the USA, $18.7 \%$ ( $n=49$, in total from 262), then, Republic of China $10.7 \%(n=28)$, Spain almost 10\% ( $n=25$ papers), Taiwan 9.5\% ( $n=25$ papers published), South Korea 7\% ( $n=19)$, Japan around 4\%, ( $n=10$ papers), Australia 3.4\% ( $n=9)$, England 3.4\% ( $n=9)$, Turkey 3\% ( $\mathrm{n}=8)$, followed by Canada, Mexico, Island, Indonesia, Italy, Malaysia, Finland, Russia, etc. In the chart below, we can see the data more in detail.

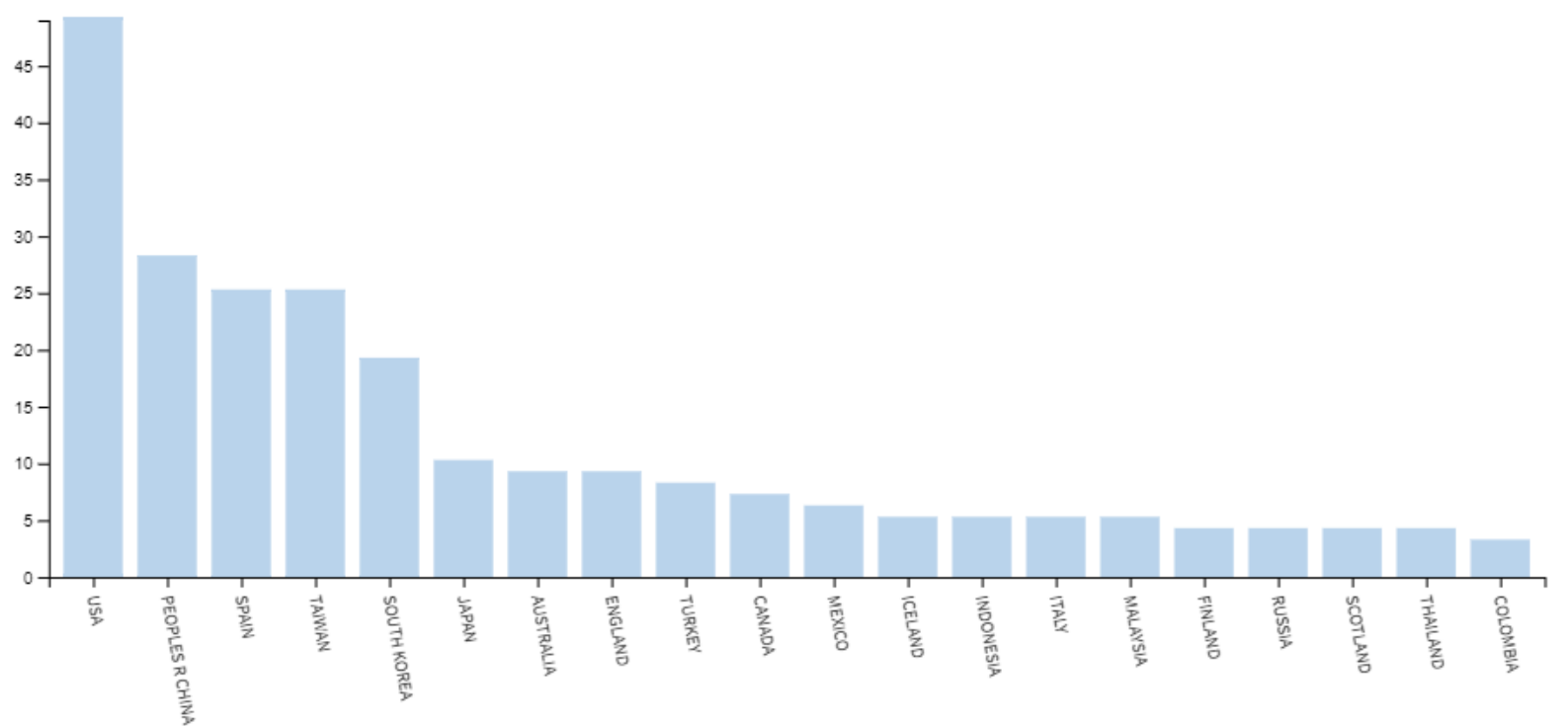

Figure 2. Number of publications per countries, sorted on a scale from the highest to the lowest

Content analysis of research papers on flipped learning. Huseyin Uzunboylu, Blerta Prevalle Ethemi y Mentor Hamidi. 
If we analyse the papers, we can see that, papers coming from the USA mainly analyse the interest of instructors in flipped learning (Baggaley, 2015), involving students within a flipped classroom methodology (Luker, Muzyka \& Belford, 2015), flipped learning as a subset of blended learning (Greener \& Watson, 2015; Rozano \& Romero, 2016), alternative methodologies of teaching like implementation of flipped and project-based learning (Howell, 2016), etc.

Research papers coming from Taiwan mainly analyse how a community language learning strategy can be most efficient in a flipped EFL classroom when used through new technology like social network Facebook (Bektas \& Fayad, 2017; Charoento, 2017; Liao et al., 2014) and transformative utilization of group - based learning in the classroom management of human resources (Huang \& Lin, 2017).

\subsection{Number of publication by funding agencies}

Funding agencies are having an important role for supporting research in many areas. In the field of flipped learning and its implication in education, there are 89 publications supported; moreover, in Taiwan, four publications (1.527\% from the total percentage) from the ministry of science and technology, 3 supported from the ministry of science and technology in Republic of China $(1.145 \%)$, in Spain also 2 supported papers by the ministry of science and technology $(0.763 \%$ from the total percentage of the published papers), followed by Alberta Innovates Health Solutions Foundation, Baxter, Bayer etc. Meaning is that the contribution of funding agencies on this particular field of education is very low.

\subsection{Number of publications by document type}

If we analyse the number of publications by document type, we can see that in Web of Science during the period from 2014 to 2018, there are 125 articles covering around $50 \%$ of the publications, 119 proceeding papers (45\% of the total percentage), 5 meeting abstracts (1.9\%), 4 editorial material (1.527\%), 4 reviews (1.527\%), 3 book reviews (1.145\%), 2 letters $(0.763 \%)$, and 1 Correction $(0.38 \%)$.

We can see the corresponding chart on the Figure 3.

Content analysis of research papers on flipped learning. Huseyin Uzunboylu, Blerta Prevalle Ethemi y Mentor Hamidi. 


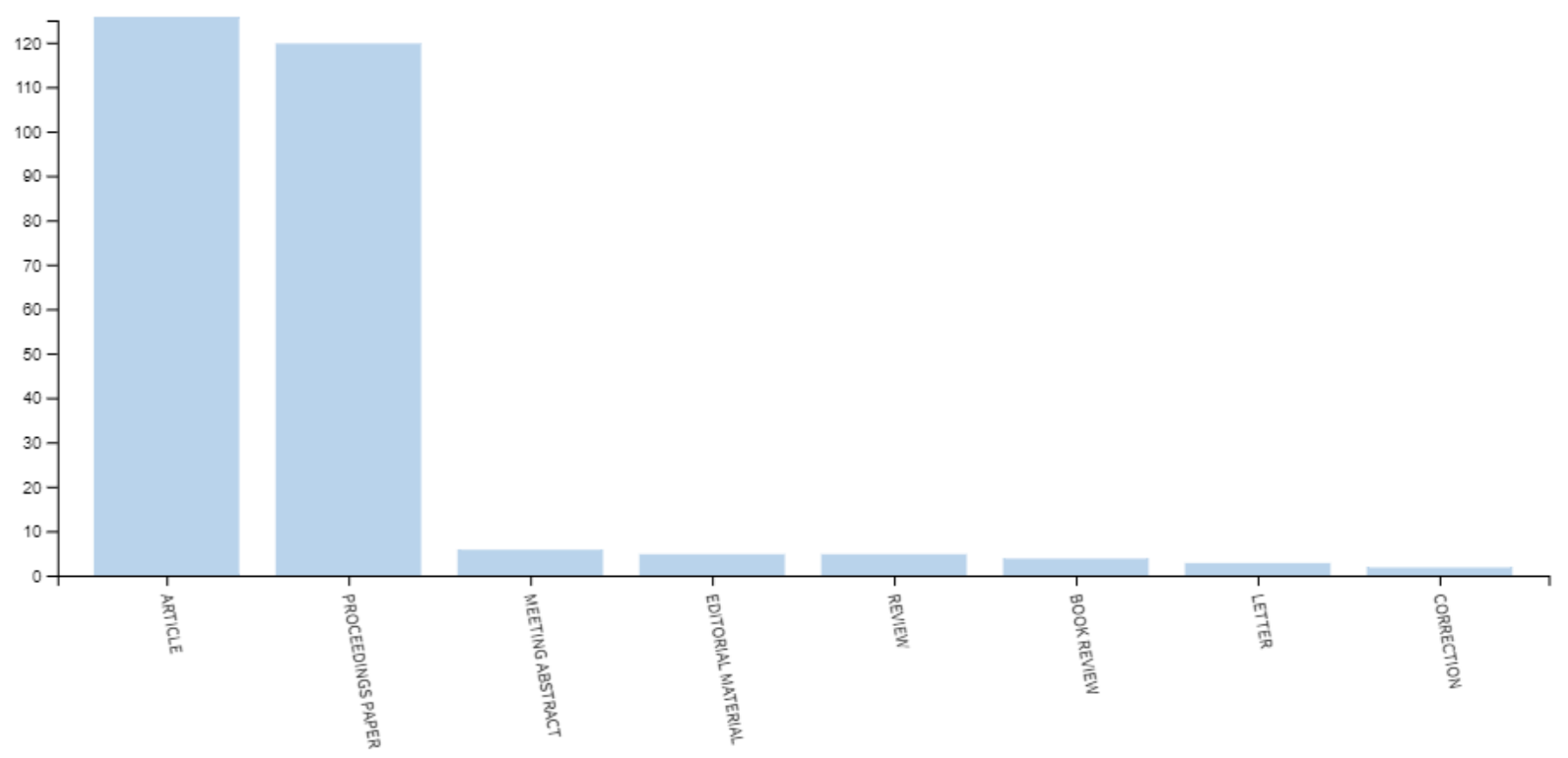

Figure 3. Number of publications by document types

\subsection{Number of publications by language}

As we know, most of the worldwide research and the academic publications are in English language, so most of the publications in Web of Science are in English and the others are in Spanish, Korean, Chinese, Turkish, French, Italian and Russian. To be more precise, more than $90 \%$ of the publications are in English $(n=237), 6.1 \%(n=16)$ in Spanish, In Korean 1.14\% $(n=$ $3)$, in Chinese and Turkish $0.76 \%(\mathrm{n}=2)$ and in the other above mentioned languages only by 1 as seen on the table below:

Table 1: Papers published by Languages

\begin{tabular}{lcc}
\hline Languages & \% of 262 & Bar Chart \\
\hline English & 237 & $90.46 \%$ \\
Spanish & 16 & $6.11 \%$ \\
Korean & 3 & $1.15 \%$ \\
Chinese & 2 & $0.76 \%$ \\
Turkish & 2 & $0.76 \%$ \\
French & 1 & $0.38 \%$ \\
Italian & 1 & $0.38 \%$ \\
Russian & 1 & $0.38 \%$ \\
\hline
\end{tabular}

Content analysis of research papers on flipped learning. Huseyin Uzunboylu, Blerta Prevalle Ethemi y Mentor Hamidi. 


\subsection{Number of publications by organisations}

In the section below, we can see the publications that come from different Organisations mainly colleges and universities and sorted from the highest number of publication that is seven, from the research being done at the National Taiwan University of Science and Technology, followed by five research publications done at University of Iceland, then, four in National Taiwan Normal University, University of Edinburgh also has done four publications and the remaining organizations with three research publications are Middle East College in Spain, University Extremadura, Utah State University, Zhejiang University,

If we analyse the publications for the research that are done at the organisations with more publication, we can see that, for example, at Middle East College in Spain is analysed how flipped learning is used as a new educational methodology in teaching mathematics. The concretization of abstract notions in teaching fundamental subjects is one of the most prevalent difficulties articulated by classroom educators in math teaching and literature (Kukey, Gunes \& Genç, 2019).

According to Pulipaka, Laigo and Bhatti (2016), flipped learning is an educational methodology that shifts the traditional way of teaching by transmitting teaching materials outside the school through online instruments. In the Department of Mathematics, the materials were transmitted by sharing video lectures or other materials for reading one week before classes. Then, students view the recorded videos and read the accompanying materials before attending school. Nearly all of the semester one modules have a lab segment, so laboratory video presentations were exchanged each prior week before starting the lab part. The results are then compared between the theory and the laboratory components of the modules that implemented flipped learning. Also, are analysed students' grades between the two components and between semesters where flipped classroom has been and has not been implemented, and how students interpret this methodology by giving to a student a survey of satisfaction.

Motivation is an important factor for university students' preferences for new learning approaches (Genc \& Ozcan, 2017). Next, the research conducted at Taiwan National University (Tao, Huang \& Tsai, 2016) was about implementing the flipped learning approach with digital game-based learning exercises for primary school learners' that study English.The research explored the impacts of learning English and the research group's interest in focus, significance,

Content analysis of research papers on flipped learning. Huseyin Uzunboylu, Blerta Prevalle Ethemi y Mentor Hamidi. 
confidence, and fulfilment. The outcomes show that the experimental groups and control groups did not have important distinctions. However, after game-based flipped teaching exercises, the experimental group showed enormous enhancement in learning achievements. In addition, the outcomes also demonstrate that the learning process based on games can advance their sense of achievement in learning, thus, motivating them to keep studying.

A detailed distribution of number of publications by organisation is presented in the chart presented in Figure 4.

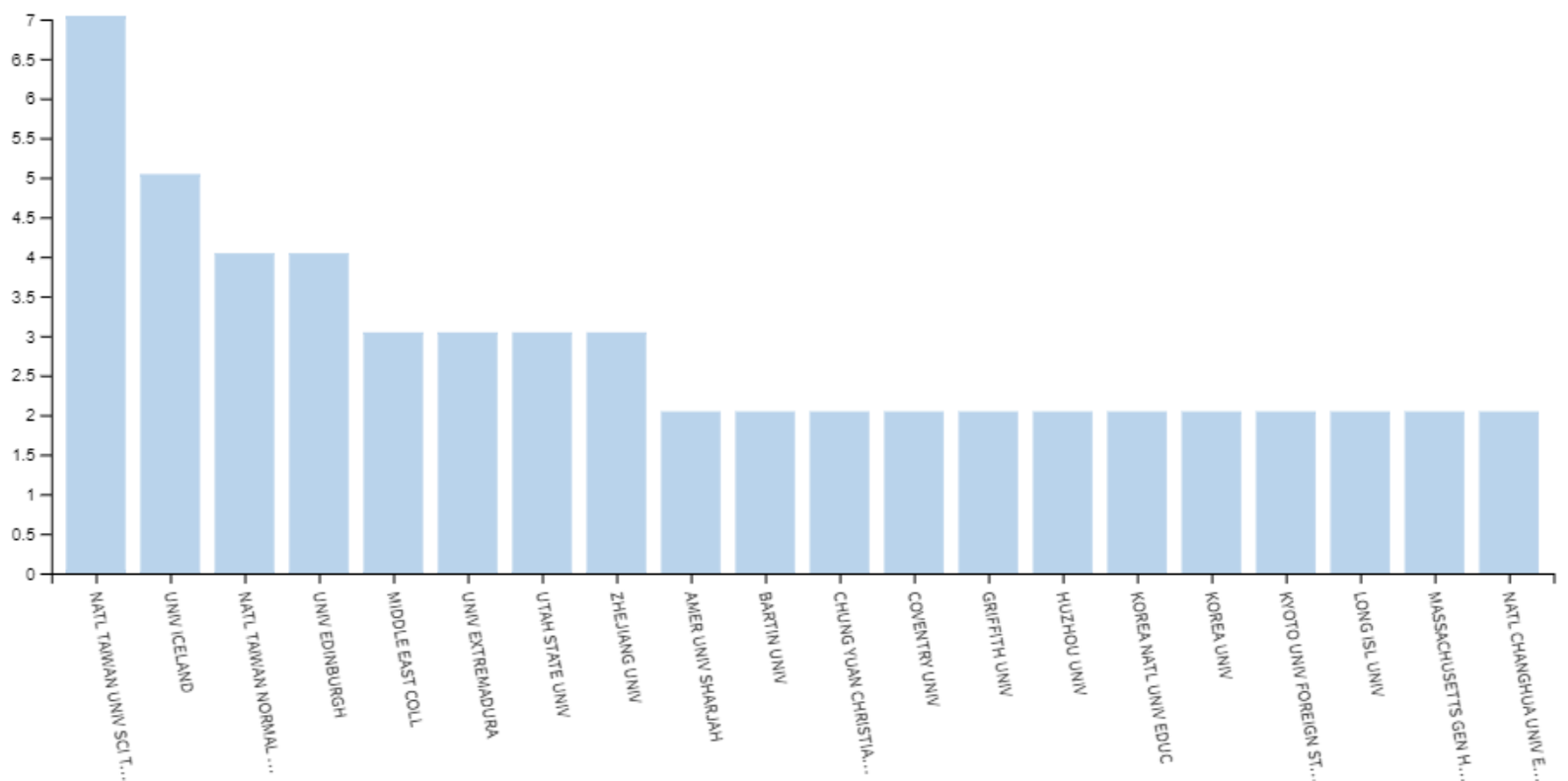

Figure 4. Number of publications by organisations

\subsection{Number of publications per year}

One of the most important parts of this study is the number of publications per year, because we want to see how the process of applying flipped learning differs in time. Even though, as we previously said, flipped learning is a concept known for the last 19 years, but still, there aren't 
eminent and efficient research that are conducted to see the influence of flipped learning and the results being presented in papers.

In this project, is analysed only the content of flipped learning in the last 5 years, published on Web of Science, in total 262 research papers.

Even though, the highest influence that flipped learning had is on 2012, the following years are the poorest with publications, only 10 in 2014, then 42 publications on 2015, which is still a small number, and on 2016, 44 research publications, followed by the most productive year on this field, 2017 when around $40 \%$ of publications were published $(n=97)$. On 2018, there were 69 papers published which mean that the interest in writing papers on Web of Science and doing research on this subject has fallen.

The papers published on 2014 were about instruments for the flipped classroom model: an experiment in the education of teachers (Fassbinder et al., 2014), the idea behind the online learning room for "Flipped Classroom" (Nielsen \& Bugge, 2014), flipped learning results: a case study in macroeconomics (Sanchez et al., 2014), the implementation of the flipped classroom in primary and secondary schools in China (Yang, 2014), the big question of rather is FLIP enough s or should we use the FLIPPED model instead? (Chen, Wang \& Kinshuk, 2014), assessment of the efficacy of flipped classroom videos (Ferrer \& Garcia - Barrera, 2014) etc.

The topics covered on 2018 publications are about: flipping large classes on a shoestring budget (Bajwa, 2018), new synthesis of flipped learning with just-in-time instruction and student response learning analytics (Prieto et al., 2018), the usage of the flipped classroom for teaching instructional desings in English at Ecuador's national university (Pineda et al., 2018) creative redesign of ICT classroom training classes: how effectiveness is affected by flipped classrooms? (Turan \& Goktash, 2018), flipped classroom - essence, development and design (Georgieva Lazarova, 2018), and so many other topics.

The distribution of number of publication papers per year that we can see in the table below and presented in the line chart in the Figure 5.

Content analysis of research papers on flipped learning. Huseyin Uzunboylu, Blerta Prevalle Ethemi y Mentor Hamidi. 
Table 2. Number of publications per year

\begin{tabular}{|c|c|c|}
\hline $\begin{array}{l}\text { Publication } \\
\text { years }\end{array}$ & $\begin{array}{l}\text { Record } \\
\text { Count }\end{array}$ & $\begin{array}{l}\text { Percentage of } \\
\text { Total }\end{array}$ \\
\hline 2014 & 10 & $3.82 \%$ \\
\hline 2015 & 42 & $16.03 \%$ \\
\hline 2016 & 44 & $16.79 \%$ \\
\hline 2017 & 97 & $37.02 \%$ \\
\hline 2018 & 69 & $26.34 \%$ \\
\hline
\end{tabular}

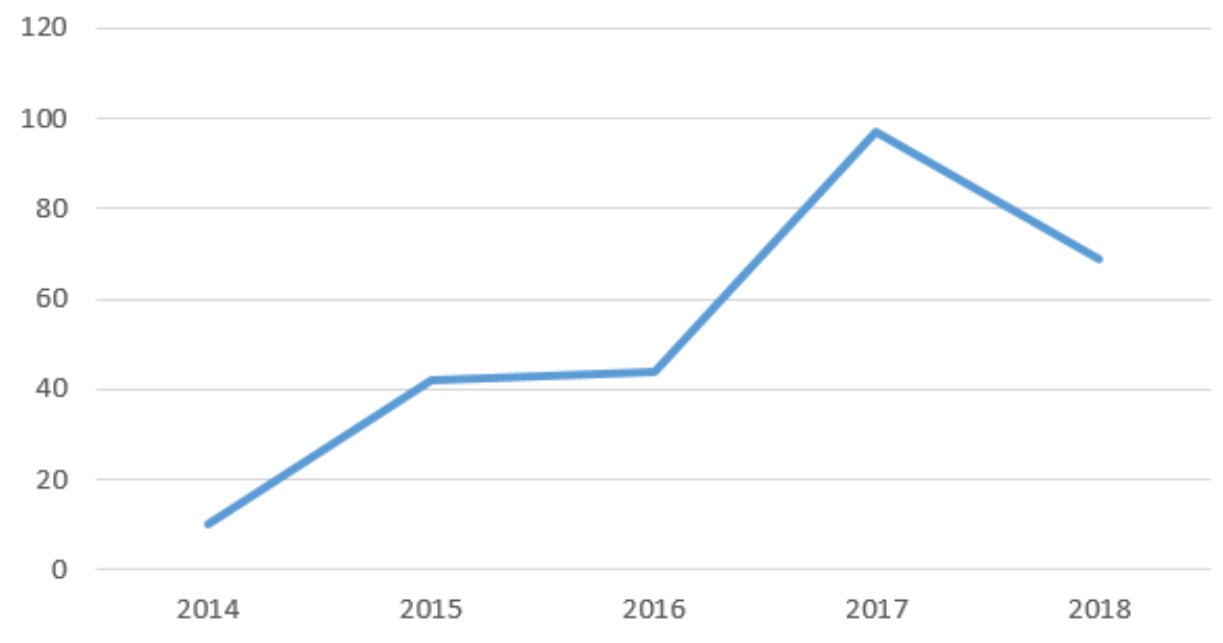

Figure 5. Number of published papers from 2014 to 2018

\subsection{Number of published papers by research areas}

There are a various number of research areas where flipped learning can be applied and give best results. According to the research papers published on Web of Science, the topics mainly covered were about education and educational research, meaning that 193 publications were on this area covering more than $73 \%$ of the total percentage, then, the next research area is computer science with 34 publications, followed by engineering 19 research papers published, then, social sciences 11 chemistry 9 , Business economics 8 , linguistics 8 , etc. The more detailed distribution we can see on the accompanying chart on Figure 6. 


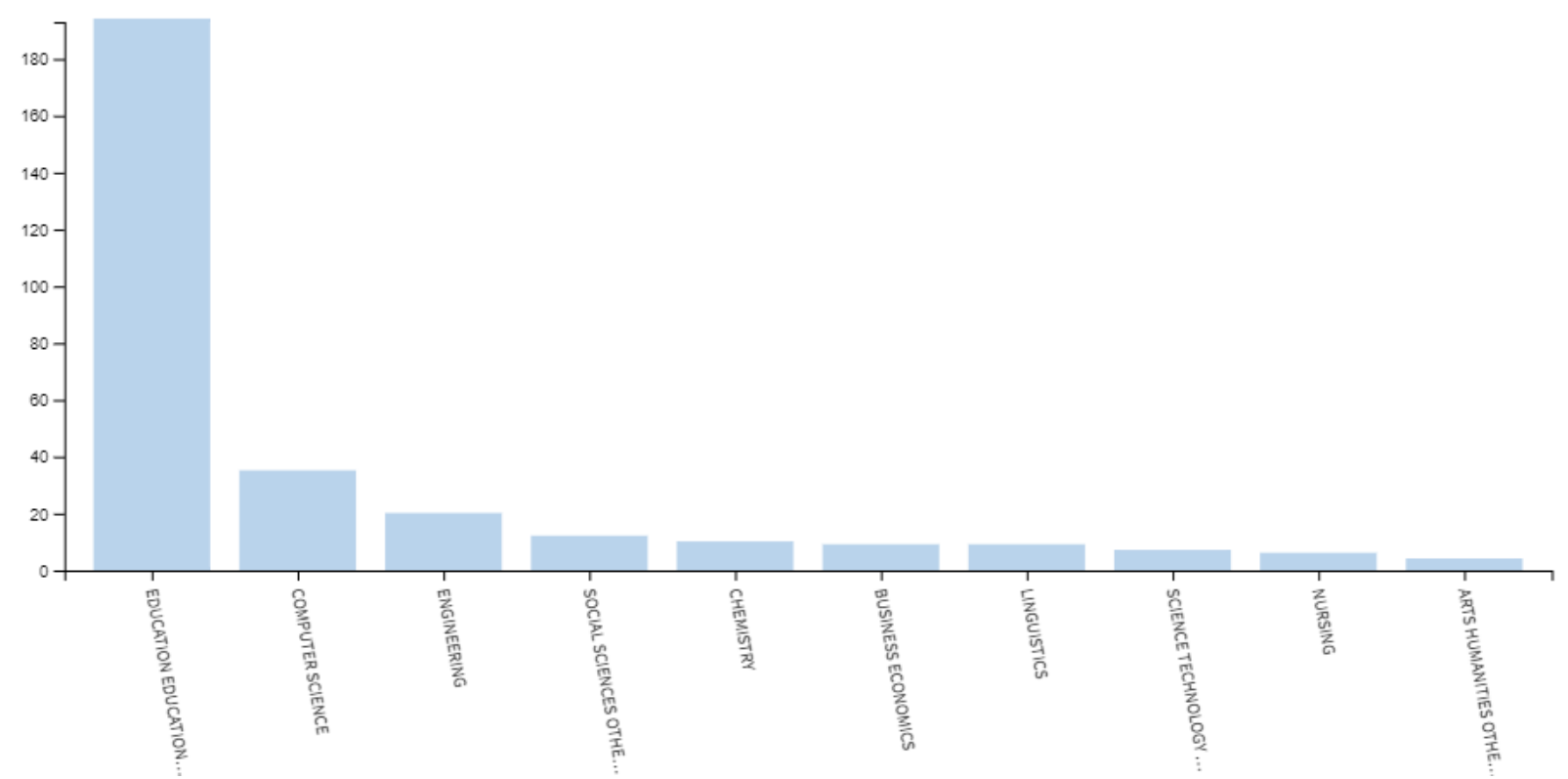

Figure 6. Number of publications by research areas

\subsection{Number of publications by source title}

The last criteria that is analysed on this paper is the number of research publications on Web of Science according to source titles. If we see the source titles by which these papers are listed, we can see that most of publications, around $8 \%$ are INTED proceedings, $(n=22)$, then ICERI proceedings $6 \%(\mathrm{n}=16)$, followed by EDULEARN Proceedings, $3.8 \%,(\mathrm{n}=10)$, and the others with less than $3 \%$ of articles being published.

The Table 2 shows the exact distribution of the published documents by source titles published on Web of Science. 
Table 2. Number of publications by source titles

\begin{tabular}{|c|c|c|}
\hline Source titles & $\begin{array}{l}\text { Number of } \\
\text { publications }\end{array}$ & $\begin{array}{l}\text { Percentage } \\
\text { of total } \\
\text { articles }\end{array}$ \\
\hline INTED PROCEEDINGS & 22 & $8.40 \%$ \\
\hline ICERI PROCEEDINGS & 16 & $6.11 \%$ \\
\hline EDULEARN PROCEEDINGS & 10 & $3.82 \%$ \\
\hline ICERI 2017 & 9 & $3.44 \%$ \\
\hline 12TH INTED CONFERENCE & 9 & $3.44 \%$ \\
\hline AISSE AND HUMANITIES RESEARCH & 8 & $3.05 \%$ \\
\hline EDUCATIONAL TECHNOLOGY SOCIETY & 6 & $2.29 \%$ \\
\hline INTED 2017 & 6 & $2.29 \%$ \\
\hline COMPUTERS EDUCATION & 5 & $1.91 \%$ \\
\hline EDULEARN15 & 5 & $1.91 \%$ \\
\hline
\end{tabular}

\section{Conclusion}

After analysing the 262 articles published on Web of Science for the flipped learning research, we can see that the mainly covered topics are about educational research, more than $73 \%$ ( $n=193$, see Figure 6), then, the next topic is computer science with $13 \%(n=34)$, which means there is a huge gap between the first well researched topic and the second one. Even though, generally speaking, flipped learning are more familiar with computers, networks and other technology facilities and we can apply this technique more easily, but still, the number of research papers on computer science and engineering is low.

Content analysis of research papers on flipped learning. Huseyin Uzunboylu, Blerta Prevalle Ethemi y Mentor Hamidi. 
Most of the papers were coming from the USA more than $18 \%(n=49$, in total from 262$)$, then, Republic of China almost 11\% $(n=28$ papers published), Spain around 10\% $(n=25)$, Taiwan 9.5\%, etc. (see Figure 2) and from the authors listed on Figure 1, most of the contribution came from Gwo - Jen Hwang, Ingibjörg B. Frímannsdóttir, Hyeonsu Kim, Yongsung Kim and Lai Ching Lung, who contributed with 19 research papers in total, around $7 \%$.

One concerning conclusion is about funding agencies, that, the number of research papers supported by funding agencies is very low, in fact, the support is only from Ministry of Science and Technology, in Taiwan ( $n=4$ from 262 publications, 1.5\%), 3 in Republic of China (1.145\%), and in Spain $2(0.763 \%)$.

If the support was bigger, there can be processed more experiments and research and the results of applying flipped learning would have been bigger and more efficient.

From analyses done on number of publications per document type, we can see that proceeding papers and articles are covering more than $95 \%$ of the total publications written in English language $90 \%$, Spanish $4 \%$ and other languages $6 \%$.

Also, an interesting finding on this analysis is the publications per year about flipped learning. Even though the concept is known from 2000, widely spread on 2012, still till 2015 there were only 52 papers published on Web of Science covering around $20 \%$ and the biggest boom it had on 2017 with more than $37 \%$ ( $n=97$ publications).

With the rise of technology and its applicability on everyday life and education, I think that this trend will arise in the next years, and also, the number of publication will become bigger, presenting real cases of flipped learning applied on the education process. So, as future issues to be considered are: what is the effect of flipped classroom approach on students' achievement? How to arise student's perception and educator's readiness to work with this kind of technique? How learning environment can meet student needs and schedules, etc.

Even though the nature of this research is descriptive, it is expected that the outcomes can provide some valuable ideas about publishing trends for research studies in flipped learning-related journals to instructors and researchers in the field of flipped learning. The review can assist researchers to identify topics, techniques and patterns of modern studies, and to comprehend the impact and influence of their main issues (Gall et al., 2004). The ability to understand trends and developments

Content analysis of research papers on flipped learning. Huseyin Uzunboylu, Blerta Prevalle Ethemi y Mentor Hamidi. 
in latest studies can assist policymakers to plan for the future, with regard to these matters (Ozcinar, 2009).

Received: October 22, 2020

Accepted: February 19, 2021

Published: April 30, 2021

Uzunboylu, H., Ethemi, B.P. \& Hamidi, M. (2021). Content analysis of research papers on flipped learning. RED. Revista Educación a Distancia, 21(66).

http://dx.doi.org/10.6018/red.451551

\section{Funding}

This research has not received any specific grant from funding agencies in the public, commercial or non-profit sectors.

\section{References}

Baggaley, J. (2016). Sandcastle competitions. Distance Education, 37 (3), 366 - 375.

Bagriyanik, S. \& Karahoca, A. (2016). Personal learning environments: a big data perspective. Global Journal of Computer Sciences: Theory and Research, 6(2), 36-46.

Bektas, C. \& Fayad, R. (2017). Learning framework using social media networks. Global Journal of Information Technology: Emerging Technologies, 7(1), 8-13. doi:10.18844/gjit.v7i1.1933

Bergmann, J. \& Sams, A. (2012). Flip your classroom: reach every student in every class every day. Washington, DC: International Society for Technology in Education. 120 - 190.

Birkollu, S. S., Yucesoy, Y., Baglama, B. \& Kanbul, S. (2017). Investigating the attitudes of preservice teachers towards technology based on various variables. TEM Journal, 6(3), 578-583.

Bishop, J. \& Verlegher, M. (2013). The flipped classroom: a survey of the research. Proceedings of 120 ASEE Annual Conference \& Exposition, Atlanta, GA: American Society for Engineering Education.

Ceker, E. \& Ozdamli, F. (2016). Features and characteristics of problem-based learning. Cypriot Journal of Educational Sciences, 11(4), 195-202. doi:10.18844/cjes.v11i4.1296

Charoento, M. (2017). Individual learner differences and language learning strategies. Contemporary Educational Researches Journal, 7(2), 57-72. doi:10.18844/cerj.v7i2.875

Content analysis of research papers on flipped learning. Huseyin Uzunboylu, Blerta Prevalle Ethemi y Mentor Hamidi. 
Cupal, M. (2016). Price Adjustments of Price-setting Factors under Sales Comparison Approach (SCA). Global Journal of Business, Economics and Management: Current Issues, 6(2), 164170. https://doi.org/10.18844/gjbem.v6i2.1381

Gall, J. E., Ku, H. Y., Gurney, K., Tseng, H. W. \& Yeh, H. T. (2004). An analysis of citation patterns in ETR\&D. In Proceedings of Association for Educational Communications \& Technology (AECT) conference, Chicago, IL, October 19-23, 2004.

Giannakos, M. N. \& Chrisochoides, N. (2014). Challenges and Perspectives in an Undergraduate Flipped Classroom Experience: Looking through the Lens of Analytics, $44^{\text {th }}$ IEEE Frontiers in Education Conference (FIE).

Genc, Z. \& Ozcan, D. (2017). Department preference motivations of teacher candidates studying in gifted education department. Ponte, 73(5), 175-184.

Giannakos, M. \& Krogstie, J. (2014). Reviewing the flipped classroom research: reflections for computer science education. Conference CSERC '14. 23 -29. Trondheim, Norway.

Greener, S., Watson, C. (2015). Flipped or Blended? What's the Difference and Does it Make a Difference to Learning in HE? Proceedings of the 10th International Conference On ELearning (ICEL 2015), Nassau, The Bahamas.146 - 151.

Gursakal, N. \& Bozkurt, A. (2017). Identifying gatekeepers in online learning networks. World Journal on Educational Technology: Current Issues, 9(2), 75-88. doi:10.18844/wjet.v9i2.1277 Hao, Y. W. (2016). Exploring undergraduates' perspectives and flipped learning readiness in their flipped classrooms. Computers in Human Behavior, 59, 82-92.

Hsieh, J. S. C., Huang, Y. M. \& Wu, W. C. V. (2017). Technological acceptance of LINE in flipped EFL oral training. Computers in Human Behavior, 70, 178-190.

Howell, R. (2016). Making the Most of a One Hour Lecture with Alternative Teaching Methodologies: Implementing Project-Based and Flipped Learning. 58th Annual Meeting and Exhibition of the American-Association-of-Physicists-in-Medicine (AAPM). 43 (6).

Huang, C.K. \& Lin, C.Y. (2017). Flipping Business Education. Educational Technology \& Society, $20(1), 323-336$.

Kanbul, S. \& Uzunboylu, H. (2017). Importance of coding education and robotic applications for achieving 21st-century skills in North Cyprus. International Journal of Emerging Technologies in Learning, 12(1), 130-140.

Content analysis of research papers on flipped learning. Huseyin Uzunboylu, Blerta Prevalle Ethemi y Mentor Hamidi.

Página 18 de 20 
Karadag, R., \& Keskin, S. (2017). The effects of flipped learning approach on the academic achievement and attitudes of the students. New Trends and Issues Proceedings on Humanities and Social Sciences, 4(6), 158-168. https://doi.org/10.18844/prosoc.v4i6.2926

Kissi, P. (2017). Proposed flipped classroom model for high schools in developing countries. New Trends and Issues Proceedings on Humanities and Social Sciences, 4(4), 150-158. https://doi.org/10.18844/prosoc.v4i4.2607

Kukey, E., Gunes, H., \& Genç, Z. (2019). Experiences of classroom teachers on the use of handson material and educational software in math education. World Journal on Educational Technology: Current Issues, 11(1), 74-86. https://doi.org/10.18844/wjet.v11i1.4010

Lage, M. J., Platt, G. J., \& Treglia, M. (2000). Inverting the Classroom: A Gateway to Creating an Inclusive Learning Environment. The Journal of Economic Education, 31 (1), 30-43.

Liao, P., Wang, L., June, J., Lee, Ch., Okuhara, K., \& Yang, H. (2014). Flipped Learning: Integrating Community Language Learning with Facebook via Computer and Mobile Technologies to Enhance Learner Language Performances in Taiwan. CT International Multidisciplinary International Social Networks Conference (MISNC) Kaohsiung, TAIWAN, $473,92-101$.

Luker, C., Muzyka, J., \& Belford R. (2015). Introduction to the Spring 2014 ConfChem on the Flipped Classroom. Journal of Chemical Education, 92 (9), 1564 - 1565.

Ozcinar, Z., (2009). The topic of instructional design in research journals: A citation analysis for the years 1980-2008. Australasian Journal of Educational Technology, 25(4), 559-580.

Rozano, M. \& Romero, J. (2016). Skill acquisition in blended learning courses: influence on student performance. International Journal of Learning and Teaching, 8(1), 30-39. doi:10.18844/ijlt.v8i1.372

Tao, S.Y., Huang, Y.H. \& Tsai, M.J. (2016). Applying the Flipped Classroom with Game-based Learning in Elementary School Students' English Learning. 5th International Conference on Educational Innovation through Technology (EITT), Tainan, Taiwan, 59 - 63.

Tsai, C.W., Shen, P.D., Chiang, Y.C. \& Lin, C.H. (2017). How to solve students' problems in a flipped classroom: a quasi-experimental approach. Universal Access in The Information Society, $16(1), 225-233$.

Content analysis of research papers on flipped learning. Huseyin Uzunboylu, Blerta Prevalle Ethemi y Mentor Hamidi. 
Umutlu, D., \& Akpınar, Y. (2017). Effects of different video modalities in flipped english writing classes on students' writing scores. New Trends and Issues Proceedings on Humanities and Social Sciences, 3(7), 60-66. https://doi.org/10.18844/prosoc.v2i7.1986

Uzunboylu, H., Hursen, C., Ozuturk, G. \& Demirok, M. (2015). Determination of Turkish University students' attitudes for mobile integrated EFL classrooms in North Cyprus and scale development: ELLMTAS. Journal of Universal Computer Science, 21(10), 1283-1296.

Uzunboylu, H. \& Kocakoyun, S. (2017). A content analysis of master and doctorate thesis in the area of gamification. International Journal of Innovative Research in Education, 3(3), 143154. doi:10.18844/ijire.v3i3.1855

Uzunboylu, H, Karagozlu D. (2015). Flipped classroom: A review of recent literature. World Journal on Educational Technology: Current Issue, Vol 7, No 2. DOI: 10.18844/wjet.v7i2.46

Uzunboylu, H., \& Cumhur, M. (2015). The content analysis of the computer-assisted studies in mathematics education between the years 2009-2014/April. International Journal of Learning and Teaching, 7(2), 62-72. DOI:10.18844/ijlt.v7i2.170

Wu, W. C. V., Hsieh, J. S. C. \& Yang, J. C. (2017). Creating an online learning community in a flipped classroom to enhance EFL learners' oral proficiency. Educational Technology \& Society, 20(20), 147-157.

Content analysis of research papers on flipped learning. Huseyin Uzunboylu, Blerta Prevalle Ethemi y Mentor Hamidi. 